\title{
Competition in a Democratic Firm System: Failures and Constraints
}

\author{
Bruno Jossa \\ University of Naples, Naples, Italy \\ Email: bruiossa@unina.it
}

How to cite this paper: Jossa, B. (2017) Competition in a Democratic Firm System: Failures and Constraints. Modern Economy, 8, 1366-1382.

https://doi.org/10.4236/me.2017.811092

Received: September 12, 2017

Accepted: November 27, 2017

Published: November 30, 2017

Copyright $\odot 2017$ by author and Scientific Research Publishing Inc. This work is licensed under the Creative Commons Attribution International License (CC BY 4.0).

http://creativecommons.org/licenses/by/4.0/

\begin{abstract}
Considering that businesses face bankruptcy when their aggregate costs exceed their revenues, the cancellation of the largest production cost item-wages and salaries-in an employee-managed firm system is an effective safeguard against bankruptcy. For this and other reasons, the author argues that risks of insolvency are unlikely to scare democratic firms into accepting the capitalistic logic of cut-throat competition.
\end{abstract}

\section{Keywords}

Labour Managed Firms, Failures, Solidarity, Comparative Economic Systems

\section{Introduction}

As is well known, in capital-managed businesses employees are paid on a monthly basis and their wage and salary claims are accorded priority treatment over those of capital providers. At the other end of the spectrum is the partners of a cooperative, who are only entitled to participate in the "residual", the balance which is left when all the firm's costs, including capital charges (but not labour costs), have been settled. This arrangement acts as a shield against bankruptcy. Considering that businesses face bankruptcy when their aggregate costs exceed their revenues, it is clear that the cancellation of the largest production cost item-wages and salaries-in an employee-managed firm system is an effective safeguard against bankruptcy. ${ }^{1}$

In addition to this, since the payments accruing to the partners constitute, not wages or salaries proper, but shares in the cooperative's distributions of the surplus, before the partners of firms with revenues below the system's average can

${ }^{1}$ In fact, this is only applicable to the theoretical model of cooperatives, whose workers earn variable incomes by definition. In real-world cooperatives, most of the partners are wage and salary earners. 
leave their firms and they have to find more efficient cooperatives prepared to take them on. In point of fact, since closed-membership firms such as cooperatives are mostly averse to the entry of new members, the workers of an all-cooperatives system will seldom be able to do so ad will just have the option of putting up with their meagre incomes or setting up a new firm.

The ultimate effect of this combination of circumstances is to make bankruptcy become the exception.

Workers risking to see their incomes zeroed must obviously be eligible for effective protection, but as this undeniably serious issue is associated with a need for state intervention in the economy, it lies outside the scope of this paper. ${ }^{2}$

Does this suggest that insolvency is a spectre that may scare democratic firms into accepting the logic of competition just as it does in capitalistic systems? Considering the greater freedom of action deriving to firms from remoter bankruptcy risks, the answer is obviously no. In other words, cut-throat competition is a distinctive characteristic of capitalistic, rather than self-managed firm systems. ${ }^{3}$

This conclusion is in full accord with Petrović's argument that the production mode as system of producer cooperatives helps overcome both "the division of society into 'quarrelling' spheres" and "the domination of the economy over other spheres" [1]; in other words, that it puts an end to the war between "quarrelling spheres" within a class society. ${ }^{4}$

Thanks to this shield against insolvency, producer cooperatives may satisfy the needs of the proletariat at least in part even in a capitalistic system. In short, although socialism can only be fully implemented in a system where employee-managed firms outnumber capitalistic businesses, the relative freedom of action enjoyed by employee-managed firms may create the assumptions for the establishment of 'socialist enclaves' in a capitalistic society.

These reflections suggest that the crisis of European socialism which the theorist of social democracy Georges Sorel traced to a marked turn towards consumerism in his day should rather be blamed on the traditional belief that socialism necessarily entails centralised planning. As is well known, when Bernstein theorised his revisionist approach, he started out from the assumption that the main obstacle to the establishment of a socialist system was not the need to help the proletariat seize power, but the difficulties attending any attempt to rapidly organise production in line with the criteria of a planned economy. No such problems would arise during the transition from capitalism to self-management socialism, which can be implemented in successive steps and without any appreciable organisational requirements.

But is the transition to socialism of worker-managed firms a realistic prospect?

Amartya Sen has argued that pessimism about the ability of society to ensure

\footnotetext{
${ }^{2}$ The argument that employee-managed firms face lesser bankruptcy risks than capitalistic businesses (though for reasons other than those mentioned in this paper) is supported by a number of empirical surveys (see, inter alia, [3] [4] and [5]).

${ }^{3}$ This is goes to support Luigi Einaudi's argument that the managers of cooperatives tend to be less pro-active than those of capitalistic businesses [6].

4"Liberation from capitalism-Lukàcs wrote [7]-means liberation from the rule of the economy".
} 
greater equality is only justified if we hold on to the belief (which Sen himself rejects) that people are exclusively concerned with maximizing their narrow personal interests [2]. Taking issue with him on this point, I wish to argue that inasmuch as self-employment is more rewarding than hired work and socialism can be established by creating a system of worker-managed or democratic firms, the ultimate advent of socialism is a material prospect even if workers, upon securing higher incomes and a measure of protection against bankruptcy, should exclusively act in their own personal interests.

\section{Solidarity in a System of Democratic Firms}

A well-known passage from the Preface to Marx's Critique of Political Economy runs as follows:

"In the social production of their existence men inevitably enter into definite relations, which are independent of their will, namely relations of production appropriate to a given stage in the development of their material forces of production. The totality of these relations of production constitutes the economic structure of society, the real foundation on which arises a legal and political superstructure, and to which correspond definite forms of social consciousness. The mode of production of material life conditions the general process of social, political and intellectual life. It is not the consciousness of men that determines their existence, but their social existence that determines their consciousness. At a certain stage of development, the material productive forces of society come into conflict with the existing relations of production or-this merely expresses the same thing in legal terms-with the property relations within the framework of which they have operated hitherto. From forms of development of the productive forces these relations turn into their fetters. Then begins an era of social revolution" $[8] .^{5}$

This often-quoted argument has been praised by a great many authors. In the estimation of Bakunin, for instance ([9], quoted in [10]), Marx offered the demonstration that economic matters had always taken precedence over legal and political issues throughout the history of societies, peoples and states and this demonstration is one of the primary achievements to his credit. ${ }^{6}$ Defining the materialist approach to history with specific reference to capitalism, Raniero Panzieri wrote [11]: "In a capitalistic economy production plays a dual role: on

${ }^{5}$ The Preface to the Critique of Political Economy includes passages explaining how Marx and Engels conceived the idea of developing the materialist conception of history and an overview of the findings they had reached and fully elucidated for the first time in The German Ideology [12]: "My inquiry led me to the conclusion that neither legal relations nor political forms could be comprehended whether by themselves or on the basis of the so-called general development of the human mind, but that on the contrary they originated in the material conditions of life, the totality of which Hegel, following the example of English and French thinkers of the eighteenth century, embraces within the term 'civil society"' [13].

${ }^{6}$ In contrast, in an analysis of the origins of morals Habermas claimed that the great eighteenth century Scots Adam Smith, Adam Ferguson and John Millar had approached this issue in a sociological key, arguing that the power structure, as well as human needs, feelings and behaviour are determined by the state of society, which in turn is determined by the configuration society has acquired over the span of its natural evolution [14]. 
the one hand, it is a specific material process; on the other, it is the general category dominating the process as a whole. If we do not understand this, we will never gain a correct appreciation of the mechanisms governing capitalistic societies."

One major assumption behind the materialist conception of history is that human character itself is affected by the institutions in place; and the influence of institutions on character suggests that one of the principal evils associated with capitalism is an adverse impact on human nature. In the words of Bataille, "the factory only knows of forces that may serve its purposes, proletarians, middlemen, accountants or technicians, but ignores the individual wherever and whenever this is possible. A firm is driven on by flameless greed; it employs labour without heart and worships its own growth as its only idol" [15].

More recently, the economist F. H. Hahn called attention to a stark contrast between the innermost driving force behind capitalism and generally recognised ethical values. Since the Jewish-Christian ethic extols virtues such as benevolence and care for our fellow-beings, condemns greed and discourages the accumulation of treasures within this world, he argues, there is nothing to be admired in individuals whose actions are solely guided by the personal profit motive, rather than the duty to take care of their fellow-beings, i.e. in anyone behaving as is expected of people operating in capitalistic systems [16]. ${ }^{7}$

These reflections indicate that individualism, the true cause of the breakup of interpersonal ties, does not proceed from democracy, but from the age-long development of capitalism, and that the establishment of a system founded on mutual solidarity between people is an absolute necessity. In capitalism-Gramsci wrote- "all the higher bonds of love and solidarity are dissolved: from the bonds of craftsmen's guilds and social castes to those of religion and the family". This is why the socialist revolution is "the spiritual revolt of humanity against the new and pitiless feudal lords of capitalism. It is the reaction of a society which is striving to remake itself as a harmonious organism, living in solidarity, governed by love and compassion". Thanks to it, "the 'citizen' is displaced by the 'comrade'; social atomism by social organization". In a system of workers' councils "limits are placed on the sway of capital in the workplace", at a stage when capitalism is still in place. "The worker wins a degree of autonomy for himself, a degree of real, effectual freedom. He is no longer one individual standing against the world: he is a member of collectivities which mesh together into other, ever greater and more powerful collectivities" [17]. ${ }^{8}$

${ }^{7} \mathrm{An}$ additional major point that cannot be examined in depth in this paper is Marcuse's claim that the inborn inclination to solidarity is stifled in a class society and that the precondition for a climate of mutual solidarity is the abolition of class divisions-the ultimate goal of a worker-controlled firm system [18].

${ }^{8}$ Elsewhere, Gramsci argued that it was still a matter for debate whether, and to what extent, criticisms of individualism were justified or, conversely, dangerous. On closer analysis, he added, the idea that a simultaneous effort to dismantle reactionary authoritarian conformity and create individuals capable of critical discernment could lead to the emergence of 'collective man' was a dialectical assumption that people accustomed to abstract schematic thinking were hardly able to understand [19]. 
The solidarity-building potential of democratic firm management was highlighted by John Stuart Mill soon after the establishment of the earliest successful producer cooperatives. More recently, its ability to counteract individualism and egotism was emphasised by Meade in a book which described the organisational structure of Agathotopia (a society imagined to be based on cooperative principles) in order to contrast the sympathetic and cooperative spirit of a typical Agathotopian with the tendency of Britons to act in accordance with the "every man for himself" criterion and grab as much as they can in the shortest time possible [20].

Accordingly, I am in full sync with C. Wright Mills when he urges the Left to socialise production means in an attempt to humanise mankind. According to this author, the belief that the new man of a free society will be forged in the factory, rather than the electoral district, explains why left-leaning groups tend to press for the permanent inclusion of worker control in the strategies and bargaining agendas of all trade union organisations [21]. In Erich Fromm's To Have or to $B e$, we read that the precondition for creating a social order founded on being, rather than having, is the active involvement of all its members in economic life as free citizens. In other words, Fromm explains, to wrest ourselves free from modes of living centred in property we have to be fully and democratically involved in industrial and political life [22].

\section{Marshall's Idea of Cooperation as a Character-Moulding Agent}

Alfred Marshall laid special stress on the beneficial effect of cooperation on character.

Specifically, he held that more than by any other influences (unless it be the influence of religious ideals), the character of a man is moulded by his every-day work and by the material resources which he thereby procures, and that consequently the two great forming agencies of the world's history have been the religious and the economic.

In a 1897 paper he wrote: "Social science or the reasoned history of man, for the two things are the same, is working its way towards a fundamental unity; just as is being done by physical science, or, which is the same thing, by the reasoned history of natural phenomena. Physical science is seeking her hidden unity in the forces that govern molecular movement: social science is seeking her unity in the forces of human character" [23]. ${ }^{9}$

The claim that human character is not given from the outset, but thoroughly shaped by the environment and its economic structure, was advanced by Marshall in earlier writings as well. In 1873, for example, he wrote "we scarcely realise how subtle, all pervading and powerful may be the effect of the work of man's body in dwarfing the growth of man" [24]. In an analysis of the relative ${ }^{9}$ Since personality is the result of the interpersonal relations entertained by an individual in society [25], it seems fairly obvious that the main focus point of social science must be the agents that shape human personality. 
weight of religious versus economic factors conducted in the Principles he argued that compared to the former, which are more intense, the latter rank higher in terms of pervasiveness since "a man's mind is absorbed by matters associated with his business even when he stops working and, as often is the case, sets out to plan future actions" [26].

The belief that work is a powerful agent shaping man's character led Marshall to argue that the main task of a social thinker was to suggest institutional reforms capable of enhancing the best qualities in man, namely the "high" ethical motives he used to contrast with the "base motives" behind capitalism, individualism and the profit motive.

All these reflections go to explain why Marshall praised the cooperative movement for its ethical motives and for its main aim: "the production of fine human beings" [27].

Overall, Marshall's approach was intended to lay stress on the potential of a genuinely democratic system to generate positive externalities and other types of benefits for society at large.

\section{Income Distribution in Market Socialism}

At this point it is worth deciding if the well-known Italian cooperation specialist Valenti is right when he argues that "cooperative societies are economic institutions designed to redress the greater part of the natural imbalances typifying the distribution of wealth in the present-day free-market system" [28].

Insofar as it is true that remoter insolvency risks scale down the impact of markets on income distribution, his argument can be endorsed since the income distribution patterns that would be substituted for the current market-determined ones would be socially determined for the most part and, hence, vouchsafe a juster social order.

Economic theorists (primarily Ward in his 1958 article) have made it clear that the workers of democratic firms should earn pay rates commensurate with pre-fixed percent shares of the firm's surplus ("coefficients"). In particular, the coefficients for entire categories of workers would have to be centrally set for the system as a whole, while those for individual workers might be fixed at firm level-with the important specification that the different production capabilities of each group are likely to induce firms to alter the centrally fixed coefficient pattern in line with firm-specific criteria.

This necessitates raising the question if distribution can be said to be 'socially determined' even under the circumstances outlined above.

In a system of cooperative firms, worker incomes differ both within one and the same firm and between different firms. They are socially determined when they depend on centrally set coefficients, but in this case the different abilities and skills of individual workers of the same category may induce firms to grant some of them higher coefficients than those centrally set. Firm-level coefficients which are fixed by the workers themselves in collective resolutions passed at 
meetings are socially determined by definition, but as the relevant choices have to be made by reference to the prevailing market conditions, they are so only in part. What really matters is whether, and to what extent, this may help avert insolvency risks and loosen market constraints.

By way of derogation from the neoclassical rule that in every market economy all prices, including those of the factors of production, are determined by the law of supply and demand, it is possible to argue that socially determined distribution coefficients will tend to reduce inequalities. Factors of production obey different supply and demand mechanisms. Demand for labour is determined by the short-term requirements of businesses, and as firms hire fresh workers according to need, it fluctuates in sync with the conditions prevailing in markets from time to time. Conversely, supply of labour is not solely determined by market factors and tends to fluctuate over considerably longer time-spans. In addition to being far less volatile, it is greatly influenced by the professional qualifications acquired by workers in training programmes, which is to say by social choices and specifically by the educational system in place.

The resulting conclusion that the prices of factors of production, unlike those of commodities, are largely unrelated to the law of supply and demand justifies the argument that income distribution is much more strongly influenced by the legal system and the political environment and much less by impersonal market forces than is usually suggested by economic theorists (on this point, see, also [29]).

Due to the crucial role of the educational system and the practice of recruitment by competitive examination, the socially determined nature of income distribution will not be fully neutralised by spontaneous market responses. In essence, the effect of hiring by competitive examinations is to balance out labour supply and demand and there is hardly any need to specify that ancillary services such as career counselling and vocational guidance are integral parts of the mission of any educational system.

On closer analysis, there is scope for arguing that the educational system and recruitment by competitive examination are ultimately designed to attain convergent goals. ${ }^{10}$ Both of them may help streamline labour supply in manners that will bring the pay rates of different worker categories into line with the desires of society. In other words, if the public hand handles labour supply in such a way as to contrive necessary demand adjustments, the pay rates assigned to the individual factors can be set at levels that social conscience will perceive as fair. ${ }^{11}$

Regarding the issue of manager coefficients in labour-managed firm systems, some authors contend that the assumed rises in worker pays would be matched by cuts on the rates of managers. On the assumption that "the hardest work of

\footnotetext{
${ }^{10}$ The idea that income distribution may be socially determined is at the basis of the movement for participatory economics promoted by Albert [30].

${ }^{11}$ In contrast, with reference to self-managed firm systems Miller [34] argues that distribution is determined by market mechanisms, but that purposeful corrective actions put in place by the State might raise social acceptability well beyond its level in capitalistic systems.
} 
business management is generally that which makes the least outward show", Marshall argued that those working with their hands tend to underrate the intensity of the strain involved in the superior work of engineering a business and, consequently, "grudge its being paid for at anything like as high a rate as it could earn elsewhere" [31]. These reflections, combining with a clear analysis of reality in his day, led Marshall to argue that no cooperative firms had so far been able to offer salaries capable of attracting first-rate managers, excepting only cases of excellent men who for the sake of the cooperative faith in them accepted a lower pay than they might have secured by offering their services in the free market.

Unlike him, Korsch suggested that the managers of democratic firms were likely to secure higher remuneration coefficients as soon as the capital owners appropriating corporate profits in our day were successfully ousted from the systems. After all, he argued, this was perfectly in line with the logic of enterprises which are managed by workers in legal terms, but depend on the abilities of their managers for their efficient running [32].

With reference to the income distribution issue, some authors, including BenNer [33], have argued that workers expected to take all business risks will hardly be prepared to put up with the volatile incomes typically associated with the varying fortunes of their firms.

To clear the field of this objection, let me specify that the optimal corporate organisation model of a worker-controlled firm is one in which payroll expenses are kept below the firm's anticipated average bottom-line result and all excess amounts are allocated to a reserve whose proceeds can be used to offset falls in the partners' revenues upon a downturn in business. An alternative option would be pooling corporate tax receipts into a social fund for use by the State in supplementing the meagre distributions likely to be made by firms in temporary financial distress (a solution which, understandably, tends to be met with fierce opposition).

The last, and fairly obvious, remark to be made at this point is that even in situations where income distribution is socially determined the State will be called upon to work towards redressing excessive inequalities, for instance by using tax receipts to award subsidies and putting in place employment-boosting policies (just as happens in capitalistic systems).

\section{Self-Management and the Challenge of Minerva}

The focus point of this section is the claim that the assumed lesser role of the private profit motive in a democratic firm system with markets can be analysed from the perspective of the "challenge of Minerva" discussed by Serge Latouche in an interesting book [35]. Latouche's approach is relevant for a number of reasons. On the one hand, it helps us realise that capitalistic markets differ greatly from the markets of cooperative firm systems; on the other, it suggests that capitalism is not only threatening to destroy the humanistic traditions native to the Mediterranean area, but even to subvert our traditional values by ad- 
vancing the thesis that despite its closer links with the humanistic tradition the South is more "backward" than the affluent North.

Minerva is the goddess of reason of the Greeks. As is well known, in Greek myth she is said to have been born directly from Jupiter's head, fully arrayed in arms, and to have two spiritual children: a daughter, Phronesis, the incarnation of prudence, wisdom and, better still, "reasonableness", and a younger son, Logos, presented as the incarnation of geometrical reason or "rationality". In Latouche's approach, Phronesis is a distinctively Mediterranean, feminine entity capable of an acute consciousness of the tragic condition of man, while Logos, a protestant masculine entity, appears to be devoid of all passion. In the modern world-he argues-the younger son is about to kill his elder sister-which is tantamount to saying that cold rationality is smothering beauty, our feminine side. Both Freud and Reich characterised capitalism as rational, patricentric and phallocratic.

Max Weber strongly criticised economics as the chronicle of the progress of economic rationalism founded on calculation, which he held to have reached a climax in the modern world. According to Latouche, people used to make a virtue of reasonableness at least until the eighteenth century, when the Western world veered towards rationality in all its problem-solving efforts.

For my part, in this Section I wish to put forward two closely associated propositions. On the one hand, a system of producer cooperatives may rise to the challenge of Minerva since softer inter-firm competition can help combine rational calculation with reasonableness; on the other, market socialism offers the advantage of safeguarding the values of humanism from the destructive impact of capitalism despite the retention of markets. In the words of Finelli [36], for the first time in the history of mankind in the capitalistic world reality came to be shaped by an abstract factor, and abstraction itself, trespassing the boundaries of its peculiar domain, logic and cognitive processes, began to build a close-meshed network of economic, practical and, more generally, behavioural, societal and cultural relations in the real world. In a self-managed firm system, this abstraction-viz. capital-is cancelled.

This prompts the interesting conclusion that the typical methodological approach known as the materialist conception of history is not relevant to every historical period and, specifically, is hardly helpful when it comes to analysing a system of producer cooperatives.

In his 1999 book, Latouche does ask himself whether people striving to maximise utility in a rational effort to keep others happy can be categorised as reasonable. As mentioned above, he starts out from the contrast between Minerva's two children, rationality and reasonableness and sets it against conceptual dichotomies previously posed within Western thought (Pascal's distinction between exprit de geometrie and esprit de finesse, Kant's and Hegel's reason versus intellect opposition, ${ }^{12}$ Pareto's distinction between logical and residual actions, Simon's distinction between bounded and global rationality). In the end, how-

${ }^{12}$ Kant used the word vernünftig. 
ever, he concludes that none of these pairs perfectly matches the rationality-reasonableness opposition and that it is definitely surprising that this dichotomy should have been overlooked right to the present day.

Due to the paramount role of economic factors within the overall issue of rational choices, Latouche's specific focus point is, quite obviously, the kind of rationality that is associated with economic calculation. While it is true that rationality is not confined to the domain of rational economic choices, he argues, given the primacy of the economic factor in today's society it is in economic life that it materialises to the full as its unmistakable paradigm. According to Latouche, the roots of rationality are in the nineteenth century, when mathematical reason was extended to morals. Descartes hoped that some day it would be possible to create a form of truly rational philosophical thinking, a philosophical approach with axioms proved true by mathematical theorems. His project to build a philosophical approach de more geometrico was first taken up by Spinoza in an effort to demonstrate that reason could clear the field of all controversy and help flesh out a moral doctrine grounded in rationality, and subsequently by Leibniz in an attempt to work out a mathematical method substituting calculation for discernment. In the estimation of Pareto, all non-economic actions are irrational.

In point of fact, it has already been mentioned that reason can be made to function in two different and even antithetical manners. One such function is reflected in quantitative appraisals, which have to do with what can be demonstrated and lead to the truth, whereas the other has to do with weighing pros against cons, i.e. judgements on moot cases which are likely to give rise to debatable choices. This means that rationality lays claim to undisputed validity, while reasonableness is associated with debate and conflict.

As argued by Latouche [35], in a non-capitalistic economy people tend to behave reasonably since they have regard to all the constituent elements of the social and human. The "reasonable reason", he argues, is manifold because it obeys more than one criterion and, hence, lays claim on embodying, according to Rawls, "a full conception of reason that covers the terms 'reasonable' and 'rational' as we often use them" [37]. And while there are people who do make cost-benefit considerations and test them against the reasonableness criterion-he added-mainstream economists deny that this holds true for the capitalistic systems of the Western world, where reasonableness was progressively relegated to a back seat at the same pace that rationality, economism and utilitarianism asserted themselves. Although the belief that reason has little to do with reasonableness is widely shared, he went on to argue, it is a fact that the plan to build a society founded on reason and the rejection of tradition and the transcendental can only be implemented by men who are guided by reason [38].

In line with a well-known Benthamite formula, the aim of society in the present-day world is to achieve the happiness of the greatest possible number of people, that is to say a geometrical form of individualistic society. The hoped-for 
result is the sum of a number of equivalence relations, for instance the one which posits that happiness $=$ pleasure $=$ standard of living $=$ gross domestic product per capita.

In a capitalistic system, people are solely concerned with needs, utility, interests and whatever may give them pleasure. From the perspective of an economist, love, hatred and passions in general can be looked upon as part of people's utility functions and, as such, enter an individual's cost/benefit calculations much like choices concerning what is to be produced and what is to be consumed. Everything can be bought and sold in the domain of the rational. According to Latouche, economics is the science of all sciences, that is to say the scientific branch which, combined with others, can help solve the totality of our problems. It is evident, economists argue, that people draw pleasure from disinterested action and that initiatives designed to make our fellow-beings happy are ultimately taken for the sake of the pleasure we derive from them. ${ }^{13}$

According to Keynes, the interpenetration of the social and economic and the final integration of the economic into society date back to the time when economic science acquired the characteristics of a form of social physics after the Newtonian rational mechanics model-a process which entailed the reduction of happiness to wealth, of wealth to utility and of utility to money. ${ }^{14}$

But why does Latouche find fault with the primacy of rationality over reasonableness? Instead of summing up his reflections, let me mention that the gist of his line of reasoning (which surprisingly is not always perfectly clear) is that happiness and pleasure are different things and that the self-respect we draw from ethical behaviour is far more rewarding than pleasure. And, as I feel very much in sympathy with him on this point, let me argue that thanks to its potential for disempowering capital and enabling workers to make free choices [even in areas associated with non-economic benefits), a system of producer cooperatives affords reconciling rational economic calculation with reasonableness.

\section{Marxism and Markets}

For all its major advantages (a beneficial effect on human nature, more equitable distribution patterns and the combination of rational economic calculation with reasonableness), self-management socialism has usually received less attention than it would have deserved. An in-depth analysis of the reasons explaining the scant concern of economists in general with this form of socialism lies outside the scope of this paper, which will just try to provide focus on the reasons accounting for the half-hearted attitude of Marxists towards democratic management.

In my opinion, Marxists are slow to recognise the importance of cooperation economics because of a strong aversion to markets. Marxist authors claiming

\footnotetext{
${ }^{13}$ Both neo-classical economists and Keynes categorised economics as a purely deductive theoretical approach. This is why Keynes wrote that "Economics is a branch of logic, a way of thinking" [39]. ${ }^{14}$ This means that following its emancipation from morals and the attainment of the status of an independent scientific discipline economics ceased making use of reasonableness.
} 
that a socialist system should promptly do away with markets and inhibit the working of market mechanisms include-to mention just one-the best-known Japanese Marxist, K. Uno, who rates socialism as antithetical to markets.

This refers us back to the question if Marx and Engels opposed markets to the point of discouraging their retention even during the transition to communism.

Engels believed that the true focus point of volume one of Capital was not capitalism proper, but just a pre-capitalistic commodity production method. In fact, this view is proved wrong by the Introduction to the Grundrisse, where we read that following a review of Hegel's Logic Marx dropped his initial plan to commence his exposition with a description of commodities production in a pre-capitalistic society and resolved to start with an analysis of capitalism. This was made clear by Bidet in a comparative analysis of the Grundrisse and Capital, which showed that the distinction between a market economy and a capitalistic system emerged much more clearly from the former than the latter. And although this did not justify any direct conclusions about the role of markets in a post-capitalist economy, he concluded, it doubtless rendered "the prospect of basing socialism on the abolition of the market less self-evident" [40]; see, also, [41]. In fact, nowhere did Marx or Engels ever claim that the instant abolition of markets was a necessary precondition for the success of a revolution.

One more explanation for the negative attitude of Marxists towards cooperation is Marx's turn away from cooperation following the collapse of the Paris Commune-probably due to the long string of failures the cooperative movement experienced from the mid-seventies of the 19th century onward. Indeed, as Marxism has always been described as a form of "scientific socialism", i.e. a theoretical approach which does not "preach" the advent of communism, but predicts it as a necessary development ${ }^{15}$ it should not come as a surprise that firms which had failed to make a success of their business were not rated as capable of ushering in communism. The cooperative form, Kautsky wrote, can only be implemented sporadically and imperfectly and will never become the prevailing form [42].

A comparable logic is perceived in a paper by the well-known Italian Marxist thinker E. Leone. According to this author, initially Marx did support a type of firm in which workers were becoming "their own capitalists" since he felt that cooperatives were living proof that the capital-labour antagonism could be transcended by turning profit-driven enterprises into socially responsible enterprises, but when the movement experienced a dramatic string of failures (in the 1860 s and 1870s), he changed his mind and resolved to theorise a different transition scenario [43].

\footnotetext{
${ }^{15}$ According to Kautsky, scientific socialists think of the struggle between warring classes, the ultimate triumph of the proletariat and the advent of socialism as necessary developments [44], while Tucker [45] objects that this belief was proved wrong upon the appearance of the Economic-Philosophical Manuscripts [in a Russian version in 1927 and the German original in 1932]. All the same, the idea of Marxism as theorising the advent of socialism as a necessary development has remained the received view right to this day [see, inter alia, [46] [47] and [48]).
} 
On closer analysis, the unenthusiastic attitude of Marxists towards cooperation can also be blamed on a political factor associated with the Bolshevik revolution: the widespread belief, throughout the past century, that the essence of socialism lay in Soviet-type centralised planning and the resulting strong stand of Marxists against anyone daring to suggest a different view of the new social order. This may explain why the idea of cooperatives as the cells of a new mode of production and the "third road" away from capitalism and central planning was widely shared until the advent of Fascism and Nazism, whereas following the turbulent Thirties and World War II cooperation lost the support of communist parties and developed into a reformist movement principally endorsed by socialists, Catholics or Protestants inimical to the idea of overthrowing capitalism. ${ }^{16}$

In part, the tepid attitude of Marxists towards cooperation can also be explained as follows.

It is well known that the natural relation between work implements and workers is capsized in capitalism: it is the human body that has to adapt to such implements and not vice versa, as would be natural. On closer analysis, however, it is worth noting that the re-reversal of the capsized capital-labour relationship expected to be triggered by democratic firm management would actually oblige society to retrace, as it were, its steps and re-adopt the pre-capitalistic organisational model. Moreover, having regard to Marx's denial of a "human nature in general" (he believed that human nature changes incessantly over time), in strictly scientific terms there is nothing to support the contention that the rereversed capital-labour relationship would be consistent with human nature. In the words of Fineschi: "If something as the essence of man did exist and if it were appropriate to read the 'natural' work process from such a perspective, the only way to eradicate estrangement would be restoring this process to its proper status, that is to say re-reversing the capsized subject-object relation typical of the capitalistic working mode and, in essence, reverting to individual work, the 'natural' process. But this is not what Marx had in mind" [51].

To refute this objection, let me stress (in contrast with Marx's maturer approach) that a human nature in general does exist, though it tends to change over time. A quote from the Economic-Philosophical Manuscripts of 1844 is clear evidence that the younger Marx did not deny the existence of a human nature in general: "Industry-he wrote-is the actual, historical relationship of nature, and therefore of natural science, to man. If, therefore, industry is conceived as the exoteric revelation of man's essential powers, we also gain an understanding of the human essence of nature, or the natural essence of man" [52]. Similarly, in the Grundrisse [53] we read that man originally appears "as a species- being (Gattungswesen), clan-being, herd animal' and even in Marx's ma-

\footnotetext{
${ }^{16}$ In fact, several authors have emphasised that the adoption of centralised planning in the Soviet Union triggered a divisive debate within the cooperative movement [see, for example, [49]). I hardly need remind the reader that "the 1917 revolution marks an unbridgeable divide, in the history of capitalism, between the pre- and post-revolutionary periods" [50].
} 
turer works, from which the idea of a general human nature has disappeared, we still perceive a persistent element of naturalism: man is no ape.

Leaving aside the issue of Marx's actual thought for the moment, there is no denying that a modern Marxist may well claim that a general human nature does exist, though it changes in accordance with the prevailing production mode. Today-let this be repeated-a man is a man and, as such, different from his ape ancestor.

Specifically, anyone denying the existence of a general human nature may nonetheless believe that within a democratic firm system such typical evils of capitalism as estrangement and alienation would at the very least be alleviated. And there can be little doubt that abating alienation is the precondition for realizing human nature to the full. Although Marx formulated his alienation theory in the Economic-Philosophical Manuscripts of 1844, when he did believe in the existence of a general human nature, nowhere in that work did he claim that the precondition for eradicating alienation was restoring the appropriate work process by re-reversing the capsized capital-labour relationship typical of capitalism. As Marx blamed alienation on markets, there are grounds for arguing that the principal factor accounting for the lukewarm support of Marxists for cooperatives is the market orientation of these firms.

For my part, I fully agree with the Marxist scholar Callari on the need for Marxists to wrest themselves free from an anti-market bias which he describes as a form of "agoraphobia" [54]. Especially, I find it hard to believe that this aversion could lead so many Marxists to overlook or altogether dismiss my proposition in this paper: the idea that the establishment of a democratic firm system would amount to a real and proper revolution against capital-the sole form of revolution feasible today.

Insofar as this is true, the tendency of Marxists to underrate the positive influence of self-management on personality and its potential for improving income distribution is at odds with the emphasis they have traditionally been laying on the alienation-generating effect of capitalism and on its adverse impact on personality and income distribution.

\section{Conclusion}

In this paper, I set out from the proposition that the establishment of a system of cooperative firms would ensure a marked fall in the number bankruptcies and afford major improvements over capitalism, including beneficial effects on personality and more equitable income distribution patterns. In the middle part, I explored the reasons that may account for the scant attention that cooperation theory has, quite surprisingly, received from mainstream and Marxist economists' right to this day. The closing section offers an attempt to refute the assumption that the democratic firm management proposal is a worn-out cliché.

\section{References}

[1] Petrović, G. (1975) Socialismo e filosofia [Socialism and Philosophy]. In: Fusi, G., 
Ed., Feltrinelli, Milan, 15.

[2] Sen, A.K. (2015) La libertà individuale come impegno sociale [Individual Freedom as a Social Commitment]. Laterza, Bari, 50.

[3] Ben-Ner, A. (1988) The Life Cycle of Worker-Owned Firms in Market Economies: A Theoretical Analysis. Journal of Economic Behavior and Organization, 10, No. 3. https://doi.org/10.1016/0167-2681(88)90052-2

[4] Stauber, L.G. (1989) Age-Dependence and Historical Effects on the Failure Rates of Worker Cooperatives; an Event-History Analysis. Economic and Industrial Democracy, 10, No. 1. https://doi.org/10.1177/0143831X89101004

[5] Dow, G. (2003) Governing the Firm; Workers' Control in Theory and Practice. Cambridge University Press, Cambridge, 226-228. https://doi.org/10.1017/CBO9780511615849

[6] Einaudi, L. (1920) Partecipazione degli operai alla gestione e socializzazione [Worker Participation in Firm Management and Socializazion]. In: Einaudi, L., Ed., Cronache economiche e politiche di un trentennio, vol. V, 1919-1920, Einaudi, Turin, 688.

[7] Lukàcs, G. (1920-1921) Kommunismus, 1920-1921 [Communism]. Marsilio Editore, Padua, 140.

[8] Marx, K. (1859) Per la critica dell'economia politica [A Critique of Political Economy]. Editori Riuniti, Rome, 5.

[9] Bakunin, M. (1873) Stato e anarchia [Statism and Anarchy]. Feltrinelli, Milan, 1968.

[10] Plekhanov, G.V. (1895) La concezione materialistica della storia [The Materialist Conception of History]. Samonà e Savelli, La Nuova sinistra, Rome, 58.

[11] Panzieri, R. (1967) Lotte operaie nello sviluppo capitalistico. [The Role of Workers' Struggles in the Evolution of Capitalism.] In: Panzieri, R., Ed. (1975), La ripresa del marxismo leninismo in Italia, Sapere Edizioni, Milan, 255.

[12] Marx, K. and Engels, F. (1845-1846) The German Ideology. In: Marx-Engels, Collected Works, Vol. 5, Lawrence \& Wishart, London.

[13] Marx, K. (1859) Per la critica dell'economia politica, trad. it., [A Critique of Political Economy.] Editori Riuniti, Rome, 4.

[14] Habermas, J. (1963) Teoria e prassi nella società tecnologica. [Theory and Practice in the Technological Society.] Ital. Transl., Laterza, Bari, 60-61.

[15] Bataille, G. (1976) il limite dell'utile. [The Limit of the Useful.] Ital. transl., Adelphi Edizioni, Milan, 64.

[16] Hahn, F.H. (1993) Il futuro del capitalismo: segni premonitori. [The Future of Capitalism: Warning Signs.] In Rivista milanese di economia, No. 46, April-June, 10.

[17] Gramsci, A. (1919-1920) l'ordine nuovo. Einaudi, Turin, 4-5.

[18] Marcuse, H. (1969) Un riesame del concetto di rivoluzione. [Re-Examination of the Concept of Revolution.] In AA.VV., 22.

[19] Gramsci, A. (1994) Scritti di economia politica. [Studies in Political Economy.] Boringhieri, Turin, 134.

[20] Meade, J.E. (1989) Agathotopia. Ital. transl., Feltrinelli, Milan, 8-9.

[21] Mills, C.W. (1948) The New Man of Power. Harcourt Brace, New York, 258.

[22] Fromm, E. (1976) Avere o essere? [To Have or To Be.] Ital. transl., Mondadori, Milan, 235.

[23] Marshall, A. (1897) The Old Generation of Economists and the New. The Quarterly 
Journal of Economics, 11, 115-135. https://doi.org/10.2307/1882124

[24] Marshall, A. (1873) The Future of the Working Classes. In: Pigou, A.C., Ed., Memorials of Alfred Marshall, Macmillan, London, 105-106.

[25] Heller, A. (1980) Per cambiare la vita. [Changing Our Ways of Life.] An Interview by Ferdinando Adornato, Editori Riuniti, Rome, 51.

[26] Marshall, A. (1890) Principles of Economics. Macmillan, London, 2.

[27] Marshall, A. (1889) Cooperation. In: Pigou, A.C., Ed., Memorials of Alfred Marshall, Macmillan, London, 228.

[28] Valenti, G. (1901) Contributo alla teoria economica della cooperazione, con un'appendice intorno alla legislazione sulle società cooperative. [A Contribution to Cooperation Theory, with an Appendix on the RelevantItalian Legislation.] In: Archivio giuridico "Filippo Serafini», nuova serie, Mucchi, Modena, 516.

[29] Fleetwood, S. (2006) Rethinking Labour Markets: A Critical-Realist-Socioeconomic Perspective. Capital \& Class, 89, 59-89. https://doi.org/10.1177/030981680608900103

[30] Albert, M. (2003) L'economia partecipativa. [An Introduction to Participatory Economics.] Datanews, Rome.

[31] Marshall, A. (1890) Principles of Economics. Macmillan, London, 292.

[32] Korsch, K. (1922) Consigli di fabbrica e socializzazione. [Workers' Councils and Socialization.] Ital. transl., Laterza, Bari, 33-34.

[33] Ben-Ner, A. (1987) Producer Cooperatives: Why Do They Exist in Capitalist Economies? In: Powel, W., Ed., The Non Profit Sector. A Research Handbook, Yale University, New Haven.

[34] Miller, D. (1989) Market, States and Community. Clarendon Press, Oxford, Chaps 6 and 7.

[35] Latouche, S. (1999) La sfida di Minerva: Razionalità occidentale e ragione mediterranea. [The Challenge of Minerva; Western Rationality versus Mediterranean Reasonableness.] Bollati Boringhieri, Ital. transl., Turin.

[36] Finelli, R. (2007) Un marxismo 'senza Capitale'. [A Model of Marxism'without Capital'.] In: Bellofiore, R., Ed., Da Marx a Marx, un bilancio dei marxismi italiani del Novecento, Manifestolibri, Rome, 132.

[37] Rawls, J. (2000) Lezioni di storia della filosofia morale. [Lectures on the History of Moral Philosophy.] Ital. transl., Feltrinelli, Milan, 177.

[38] Rawls, J. (2000) Lezioni di storia della filosofia morale. [Lectures on the History of Moral Philosophy.] Ital. transl., Feltrinelli, Milan, 65.

[39] Keynes, J.M. (1938) The Collected Writings of John Maynard Keynes, Macmillan, London, Vol. XIV, 296.

[40] Bidet, J. (2001) New Interpretations of Capital. In: Bidet, J. and Kouvelakis, S., Eds., Critical Companion to Contemporary Marxism, Engl. Transl., Brill, Leiden and Boston, 377.

[41] Petrucciani, S. and Russo, M. (2010) Presentazione. Leggere il Capitale per comprendere la modernità. [Foreword to Reading Capital in Order to Understand Modernity.] In: Bidet, J., Ed., Il Capitale', spiegazione e ricostruzione [Esplanation and Reconstruction of Marx's ' Capital .], Ital. transl., manifestolibri, Rome, 12.

[42] Kautsky, K. (1892) Introduzione al pensiero economico di Marx. [An Introduction to the Economic Doctrines of Karl Marx.] Ital. transl., Laterza, Bari, 109.

[43] Leone, E. (1902) Sul principio di cooperazione nei suoi rapporti con il socialismo. 
[On the Principles of Cooperation and Their Relationship with Socialism.] Critica Sociale, XII, 287.

[44] Kautsky, K. (1907) Ethics and the Materialist Conception of History. C. H. Kerr, Chicago, 202.

[45] Tucker, R.C. (1961) Philosophhy and Myth in Karl Marx. Cambridge University Press, Cambridge, Introduction.

[46] Altvater, E. (1968) L'attualità del Capitale. [The Topicality of Capital.] In AA. VV., Cent'anni dopo il Capitale, Ital. transl., Samonà e Savelli, Rome.

[47] Poulantzas, N. (1968) Brevi note sull'oggetto del Capitale. [Notes on the Subject of 'Capital'.] In AA. VV., Cent'anni dopo il Capitale, Ital. transl., Samonà e Savelli, Rome.

[48] Murgescu, C. (1969) Alcune riflessioni sommarie in occasione di un anniversario. [A Few Reflections Developed on the Occasion of an Anniversary.] In AA. VV., Marx vivo, Mondadori, Milan, 196.

[49] MacPherson, I. (2008) The Cooperative Movement and the Social Economy Traditions: Reflections on the Mingling of Broad Visions. Annals of Public and Cooperative Economics, 79, 635, 639.

[50] Strada, V. (1982) Marxismo e post-marxismo. [Marxism and Post-Marxism.] In: Hobsbawm, E.J., Haupt, G., Marek, F., Ragionieri, E., Strada, V. and Vivanti, C., Eds., Storia del marxismo, 5 Vols,. Einaudi, Turin, 87.

[51] Fineschi, R. (2006) Marx e Hegel; contributi ad una rilettura. [Re-Reading Marx and Hegel.] Carocci, Rome, 101.

[52] Marx, K. (1844) Economic and Philosophical Manuscripts of 1844. In: Marx-Engels, Collected Works, Vol. 3, Lawrence \& Wishart, London.

[53] Marx, K. (1857-1858) Grundrisse: Introduction to the Critique of Political Economy. Pelican Books, London, 121; Italics Added.

[54] Callari, A. (2009) A Methodological Reflection on the 'Thick Socialism' of Socialism after Hayek. Review of Social Economy, XVII, 368.

https://doi.org/10.1080/00346760802014813 